\section{Silica Sprays Reduce the Incidence and Severity of Bract Necrosis in Poinsettia}

\author{
Richard J. McAvoy and Bernard B. Bible \\ Department of Plant Science, University of Connecticut, Storrs, \\ CT 06269-4067
}

Additional index words. sodium silicate, calcium, Euphorbia pulcherrima

\begin{abstract}
Silica sprays $\left(\mathrm{Na}_{2} \mathrm{SiO}_{3}\right.$ or $\left.\mathrm{SiO}_{2} \cdot n \mathrm{H}_{2} \mathrm{O}\right)$ markedly reduced the incidence and severity of bract necrosis (BN) of Euphorbia pulcherrima Willd. cv. Supjibi Red compared to plants not sprayed with silica. BN has been associated with low Ca concentrations or high $\mathrm{K}$ : Ca ratios in tissues of bract margins. Silica had no effect on Ca or $\mathrm{K}$ concentrations in bract margin tissues, and BN was not associated with the macro- or micronutrient composition of bract margin tissues. Sixteen days after initial anthesis, nontreated and deionized-water-sprayed poinsettias developed a higher incidence of $\mathrm{BN}$ than did plants sprayed with $\mathrm{Na}_{2} \mathrm{SiO}_{3}$ or $\mathrm{CaCl}_{2}$. However, sprays of 3.56, 5.34, and 7.12 $\mathrm{mM} \mathrm{Na}_{2} \mathrm{SiO}_{3}$ were as effective as $9.98 \mathrm{~mm} \mathrm{CaCl}_{2}$ sprays in protecting against $\mathrm{BN}$ of 'Supjibi Red' and 'Angelika White' bracts for up to 30 days after initial anthesis. 'Supjibi Red' developed a higher incidence of bract necrosis than did 'Angelika White', but both cultivars showed a similar response to the treatments and similar symptoms of necrosis. In both cultivars, initial symptoms appeared as small necrotic lesions on bracts at the looped ends of lateral veins that displayed a closed-vein pattern after the plants reached initial anthesis.
\end{abstract}

Bract necrosis $(\mathrm{BN})$ is a serious disorder of the poinsettia, characterized by small brown spots or lesions near the bract margins that begin to appear soon after plants reach initial anthesis (Moe et al., 1992; Nell and Barrett, 1986). As symptoms progress, the spots enlarge, darken, and the number of bracts affected increases until the appearance of the poinsettia is seriously degraded. Stromme et al. (1994) observed a Ca gradient in poinsettia bracts with higher concentrations in midportions of bracts and lower concentrations in the bract margins. Woltz and Harbaugh (1986) demonstrated that Ca sprays, applied to bracts during their development, suppressed $\mathrm{BN}$ in 'V-14 Glory' bracts. They concluded that a deficiency of $\mathrm{Ca}$ in bract margins caused $\mathrm{BN}$.

At first glance, $\mathrm{BN}$ of poinsettia is another instance of a disorder resulting from localized $\mathrm{Ca}$ deficiencies, but is it? Localized Ca deficiencies cause necrosis in the tissues of various plant species, including leaf-edge burn of the poinsettia (Bierman et al., 1990), blackheart of young celery (Apium graveolens L.) leaves (Bible and Stiehl, 1986), and tipburn of young Chinese cabbage (Brassica rapa $\mathrm{L}$. Pekinensis Group) leaves (Van Berkel, 1988). The one common characteristic in these three examples is that the necrosis appears on young tissues during rapid cell expansion. However,

\footnotetext{
Received for publication $21 \mathrm{Feb} .1996$. Accepted for publication 25 June 1996. Storrs Agricultural Experiment Station scientific contribution no. 1668. This research was funded, in part, by the New England Greenhouse Conference, the Univ. of Connecticut Research Foundation, and the Storrs Agricultural Experiment Station. The cost of publishing this paper was defrayed in part by the payment of page charges. Under postal regulations, this paper therefore must be hereby marked advertisement solely to indicate this fact.
}

with $\mathrm{BN}$, it is the mature bracts that show the first evidence of necrosis as they begin to age, at or shortly after anthesis (McAvoy and Bible, 1994).

Elevated nighttime humidity suppresses blackheart of celery (Bible and Stiehl, 1986) and tipburn of Chinese cabbage (Van Berkel, 1988), whereas it does not suppress BN of the poinsettia (Stromme et al., 1994). Furthermore, Nell and Barrett (1986) reported that water stress (to wilt) applied to poinsettias during bract development did not affect the incidence of BN, unlike water stress induced edge burn of poinsettia leaves (Jacques et al., 1990). In fact, when poinsettias were exposed to abundant water and high fertilizer levels, applied from the onset of bract coloration until anthesis, BN increased (Nell and Barrett, 1986). Although Ca sprays suppress BN, the fundamental cause of this poinsettia disorder is unclear.

The symptoms of $\mathrm{BN}$ are similar to the necrotic spots on the margins of lettuce (Lactuca sativa L.) leaves. This lettuce disorder can be suppressed by silicate applications (Blatt and Van Diest, 1981). Also, silica treatments suppress the development of necrotic freckling on sugar cane (a complex trispecies hybrid of Saccharum) leaves (Elawad et al., 1982) and barley (Hordeum vulgare) leaves (Williams and Vlamis, 1957). Based on the nature of the symptoms, we speculated that silicate applications might reduce $\mathrm{BN}$ in poinsettia. The objectives of our study were to determine the effects of silica treatments on $\mathrm{BN}$, and compare the efficacy of silica, over time, to the standard calcium chloride $\left(\mathrm{CaCl}_{2}\right)$ spray treatment.

\section{Materials and Methods}

Experiments were conducted in a glass greenhouse with temperature set points main- tained at $21{ }^{\circ} \mathrm{C}$ day $/ 17^{\circ} \mathrm{C}$ night. Rooted cuttings of 'Supjibi Red' in 1993/94 and 'Supjibi Red' and 'Angelika White' in 1994/95 were grown in Metro Mix 510 medium (O.M. Scott, Marysville, Ohio) with manual irrigation. In all cases, plants were treated with the fungicide Phyton 27 (21.36\% copper sulphate pentahydrate; Source Tech. Biologicals, Minneapolis) at $6.25 \mathrm{ml} \cdot \mathrm{L}^{-1}$ just after bract necrosis was first evident to protect against secondary fungal infection on necrotic tissues. Treatments were arranged in a randomized block design with 16 single-plant replications in Expt. 1 and 10 in Expt. 2. All data were analyzed using analysis of variance procedures.

'Supjibi Red'- $\mathrm{Na}_{2} \mathrm{SiO}_{3}$ sprays and drenches (Expt. 1). Poinsettias treated with either topical sprays or potting medium drenches of sodium silicate $\left(\mathrm{Na}_{2} \mathrm{SiO}_{3}\right)$ were compared to nontreated (control) plants. The $17.8 \mathrm{mM} \mathrm{Na}_{2} \mathrm{SiO}_{3}$ solution, used for the spray and drench treatments, was made with deionized water.

'Supjibi Red' cuttings were transplanted into $0.5 \mathrm{~L}$ pots on 19 Aug. 1993, watered in with $\mathrm{N}$ at $14.3 \mathrm{~mol} \cdot \mathrm{m}^{-3}\left(200 \mathrm{mg} \cdot \mathrm{L}^{-1}\right)$ from a $5 \mathrm{~N}-6.9 \mathrm{P}-14.1 \mathrm{~K}$ fertilizer, and subsequently pinched on 1 Sept. leaving four to five nodes per plant. Photoperiod lighting $\left(2 \mu \mathrm{mol} \cdot \mathrm{m}^{-2} \cdot \mathrm{s}^{-1}\right)$ was provided from 2200 to $0200 \mathrm{HR}$ nightly from 30 Aug. to 12 Oct. 1993. After transplanting, plants were irrigated with $\mathrm{N}$ at 14.3 $\mathrm{mol} \cdot \mathrm{m}^{-3}$ from a $15 \mathrm{~N}-2.2 \mathrm{P}-20.8 \mathrm{~K}$ fertilizer on a constant basis until 8 Oct., and then with 14.3 $\mathrm{mol} \cdot \mathrm{m}^{-3}$ from $\mathrm{Ca}\left(\mathrm{NO}_{3}\right)_{2}$ until 23 Oct. From 23 Oct. to $1 \mathrm{Nov}$., $\mathrm{N}$ at $14.3 \mathrm{~mol} \cdot \mathrm{m}^{-3}$ from a $15 \mathrm{~N}-$ $2.2 \mathrm{P}-20.8 \mathrm{~K}$ fertilizer was applied at each irrigation. The rate was increased to $17.9 \mathrm{~mol} \cdot \mathrm{m}^{-}$ ${ }_{3}^{3}\left(250 \mathrm{mg} \cdot \mathrm{L}^{-1}\right)$ on 1 Nov. and continued until the end of the study (5 Feb. 1994). At harvest, potting medium electrical conductivity (EC) averaged $1.7 \mathrm{dS} \cdot \mathrm{m}^{-1} \pm 0.1 \mathrm{SE}$ (using a $1 \mathrm{me}$ dium : 2 water extraction). The raw water used for irrigation had an alkalinity of $\mathrm{CaCO}_{3}$ at $49.3 \mathrm{mg} \cdot \mathrm{L}^{-1}$, an $\mathrm{EC}$ of $0.15 \mathrm{dS} \cdot \mathrm{m}^{-1}$, and a $\mathrm{Ca}$ and $\mathrm{Mg}$ concentration of 7.98 and $1.96 \mathrm{mg} \cdot \mathrm{L}^{-1}$, respectively.

The spray and drench treatments with the $17.8 \mathrm{~mm} \mathrm{Na}_{2} \mathrm{SiO}_{3}$ began on 15 and 8 Nov. respectively, and continued at weekly intervals until initial anthesis (13 Dec. 1993). Beginning 31 days later, on 13 Jan. 1994, the number of necrotic bracts per plant was recorded each week until 5 Feb. The percent incidence of bract necrosis was calculated by dividing the number of necrotic bracts by the total number of bracts per plant $(\times 100)$. These data were used to compare relative differences in the development of $\mathrm{BN}$ over time in response to the treatments.

On 5 Feb., all plants were harvested, bracts counted, and each bract rated for severity of necrosis where $1=$ healthy; 2 = less than or equal to five necrotic spots per bract and lesions not expanded beyond the looped-end of the lateral vein (where necrotic symptoms first appear); 3 = less than or equal to five necrotic spots per bract and at least one lesion enlarged beyond the area of the looped-end of the lateral vein; $4=$ six to ten necrotic spots per 
bract with most expanded beyond the affected vein; $5=11$ to 15 spots per bract; $6=$ greater than 15 spots per bract. The ratings were multiplied by the number of bracts in each category, and the sum of these values $(\times 100)$ was divided by the total number of bracts to obtain the total necrosis index (TNI). This value represents the incidence of bract necrosis weighted for severity; a TNI value of 100 would represent no damage and a value of 600 would represent a plant with category 6 damage on all bracts. The TNI is the best measure of overall poinsettia damage because it combines both the severity rating and the percent incidence in a single index.

After bracts were evaluated for damage, the tissue was processed for nutrient analysis. Bract samples were washed with $0.1 \mathrm{~N} \mathrm{HCl}$ for $60 \mathrm{~s}$ and then rinsed in deionized water. Tissue from a 1- to 1.5-cm-wide strip along each bract margin was collected from all bracts on each plant and dried at $70^{\circ} \mathrm{C}$. Because the quantity of tissue from each plant was too small for complete nutrient analysis, samples from adjoining replicated blocks were combined to yield four samples for each treatment group. Samples were then ground to pass a 0.25 $\mathrm{mm}^{2}$-pore mesh screen, and analyzed for mineral nutrient content with an ICP-emission spectrophotometer (Thermo Jarrell Ash, Franklin, Mass.) using the dry ash procedure (Cornell Univ., Fruit and Vegetable Science Analytical Lab, Ithaca, N.Y.).

'Supjibi Red' and 'Angelika White'$\mathrm{Na}_{2} \mathrm{SiO}_{3}$ or CaCl $\mathrm{Sprays}_{2}$ (Expt. 2). In 1994/95, 'Supjibi Red' and 'Angelika White' were transplanted into 1.6-L pots on 8 Aug. 1994 and subsequently pinched on 2 Sept. leaving four to five nodes per plant. Photoperiod lighting (2 $\mu \mathrm{mol} \cdot \mathrm{m}^{-2} \cdot \mathrm{s}^{-1}$ ) was provided from 2200 to 0200 HR nightly from $30 \mathrm{Aug}$. to $26 \mathrm{Sept}$. All plants were fertilized on a constant basis using $\mathrm{N}$ at $14.3 \mathrm{~mol} \cdot \mathrm{m}^{-3}\left(200 \mathrm{mg} \cdot \mathrm{L}^{-1}\right)$ from a $15 \mathrm{~N}-2.2 \mathrm{P}$ $20.8 \mathrm{~K}$ alternating with $14.9 \mathrm{~mol} \cdot \mathrm{m}^{-3}\left(208 \mathrm{mg} \cdot \mathrm{L}^{-}\right.$ $\left.{ }^{1}\right)$ from $\mathrm{Ca}\left(\mathrm{NO}_{3}\right)_{2}$ every third irrigation.

Spray solutions were prepared using $\mathrm{Na}_{2} \mathrm{SiO}_{3}$ or $\mathrm{CaCl}_{2}$, deionized water, and a surfactant (Triton-B; 77\% phthalic glycerol alkyd resin) at $0.1 \mathrm{mg} \cdot \mathrm{L}^{-1}$ was included. The spray rates were $\mathrm{Na}_{2} \mathrm{SiO}_{3}$ at 1.78, 3.56, 5.34, and $7.12 \mathrm{~mm}$ and $\mathrm{CaCl}_{2}$ at $9.98 \mathrm{~mm}$. A nonsprayed control and a sprayed control using deionized water with the surfactant were included. The first sprays were applied at initial bract coloring (31 Oct.) and the plants subsequently were sprayed four more times at weekly intervals until anthesis (5 Dec.).

Beginning on 14 Dec. 1994, the number of necrotic bracts per plant was recorded each week until 11 Jan. 1995. On 16 Jan., all plants were harvested and bracts counted and rated for severity of BN using the criteria previously described for Expt. 1. Treatment effects were compared using single-degree-of-freedom orthogonal contrasts.

\section{Results}

'Supjibi Red'- $\mathrm{Na}_{2} \mathrm{SiO}_{3}$ sprays and drenches (Expt. 1). Poinsettias sprayed with $\mathrm{Na}_{2} \mathrm{SiO}_{3}$ showed no visible signs of $\mathrm{BN}$ until
31 days afterinitial anthesis (Fig. 1). Nontreated plants developed necrotic lesions on $12 \%$ of bracts by 31 days after initial anthesis, while only $0.4 \%$ of the bracts on $\mathrm{Na}_{2} \mathrm{SiO}_{3}$ sprayed plants displayed necrotic lesions by this date. Once BN began to develop, the percentage of affected bracts on poinsettias in all three treatment groups increased at a steady linear rate over time $\left(r^{2}=0.99,0.98,0.93\right.$ for the nonsprayed, $\mathrm{Na}_{2} \mathrm{SiO}_{3}$ drenched, and $\mathrm{Na}_{2} \mathrm{SiO}_{3}$ sprayed plants, respectively). However, the rate of increase in the incidence of $\mathrm{BN}$ was much higher for the nonsprayed and $\mathrm{Na}_{2} \mathrm{SiO}_{3}$ drenched plants $(9 \%$ and $12 \%$ per week, respectively) than for the $\mathrm{Na}_{2} \mathrm{SiO}_{3}$ sprayed plants (4.5\% per week).

At harvest, $\mathrm{Na}_{2} \mathrm{SiO}_{3}$ sprays had reduced both the incidence and severity of BN compared to nontreated plants. The total necrosis index $(\mathrm{TNI}=129)$ for $\mathrm{Na}_{2} \mathrm{SiO}_{3}$ sprayed plants was $39 \%$ lower than for the nontreated plants (TNI $=212)$ and $49 \%$ lower than for the plants drenched with $\mathrm{Na}_{2} \mathrm{SiO}_{3}(\mathrm{TNI}=255)$. Thus, drenching the potting medium with a $17.8 \mathrm{~mm}$ $\mathrm{Na}_{2} \mathrm{SiO}_{3}$ solution was ineffective for controlling BN.

Sodium silicate sprays increased the $\mathrm{Na}$ content of bract margin tissue relative to the nontreated plants $(0.13 \%$ vs. $0.04 \%$ of dry mass, respectively); the $\mathrm{Na}_{2} \mathrm{SiO}_{3}$ drench did not affect the $\mathrm{Na}$ concentration in bract margins $(0.04 \%$ of dry mass). There was no effect of the $17.8 \mathrm{~mm} \mathrm{Na}_{2} \mathrm{SiO}_{3}$ spray or drench on contents of macro- or micronutrients in the bract margin tissue other than $\mathrm{Na}$. The average macronutrient levels measured in bract margins were (all in percentage of dry mass) 0.74 for P, 3.5 for $\mathrm{K}, 0.19$ for $\mathrm{Ca}$, and 0.41 for $\mathrm{Mg}$. The average micronutrient concentration measured in bract margins were (all in $\mu \mathrm{g} \cdot \mathrm{g}^{-1}$ of dry mass) 17.5 for $\mathrm{Mn}, 89$ for $\mathrm{Fe}, 23.9$ for $\mathrm{Cu}, 49.2$ for $\mathrm{Zn}, 5.5$ for Mo, and 26.5 for B; Al averaged 109.

'Supjibi Red' and 'Angelika White'$\mathrm{Na}_{2} \mathrm{SiO}_{3}$ or $\mathrm{CaCl}_{2}$ sprays (Expt. 2). The incidence and severity of BN was slightly higher on 'Supjibi Red' than on 'Angelika White', but both cultivars showed a similar response to the treatments (Table 1) and similar symptoms of BN (Fig. 2). In both cultivars, initial symptoms appeared as small necrotic lesions at the looped ends of lateral veins that displayed the closed-vein pattern after the plants had reached anthesis.

Poinsettias not sprayed with $\mathrm{Na}_{2} \mathrm{SiO}_{3}$ or $\mathrm{CaCl}_{2}$ were the most prone to $\mathrm{BN}$ (Fig. 3). As in Expt. 1, necrotic lesions first began to appear on mature bracts in the weeks following initial anthesis. By 16 days after initial anthesis, $5.7 \%$ of the bracts on nonsprayed controls had developed necrotic lesions while only $0.2 \%$ of the bracts on plants sprayed with 9.98 $\mathrm{mm} \mathrm{CaCl} \mathrm{Cl}_{2}$ developed necrotic spots and only $0.1 \%$ of the bracts of plants sprayed with 3.56 mM $\mathrm{Na}_{2} \mathrm{SiO}_{3}$ showed evidence of BN. By 30 days after initial anthesis, the incidence of $\mathrm{BN}$ was similar for plants sprayed with $\mathrm{CaCl}_{2}$ at $9.98 \mathrm{~mm}$ and $\mathrm{Na}_{2} \mathrm{SiO}_{3}$ at $3.56 \mathrm{~mm}$ or higher ( $0.4 \%$ and $2.7 \%$, respectively), but was higher on deionized water sprayed controls (14.8\%), and still higher on nontreated plants (19.9\%).
At harvest (47 days after initial anthesis), the incidence of $\mathrm{BN}$ was highest on nontreated plants and lowest on $\mathrm{CaCl}_{2}$-sprayed poinsettias. During the interval from 16 to 47 days after initial anthesis, the incidence of $\mathrm{BN}$ increased at a steady linear rate in all treatments (Fig. 3). Bract necrosis increased at a rate of $6.4 \%$ and $5.5 \%$ per week on nonsprayed and deionized water sprayed poinsettias, respectively, but only $0.2 \%$ per week on poinsettias sprayed with $9.98 \mathrm{mM} \mathrm{CaCl}_{2}$, and $2.2 \%$ per week on poinsettias sprayed with $3.56 \mathrm{~mm}$ $\mathrm{Na}_{2} \mathrm{SiO}_{3}$.

At harvest, the incidence of $\mathrm{BN}$ on $\mathrm{Na}_{2} \mathrm{SiO}_{3}$ treated poinsettias was higher than on $\mathrm{CaCl}_{2}-$ treated plants (Table 1). While sprays of deionized water plus surfactant suppressed BN to a lesser extent than silica or $\mathrm{Ca}$, they did slightly reduce $\mathrm{BN}$ compared to nontreated plants. Overall, 'Supjibi Red' developed a higher incidence of $\mathrm{BN}$ and the symptoms were more severe than for 'Angelika White' (as indicated by the total necrosis index), but both cultivars showed a similar response to treatments.

\section{Discussion}

Our results clearly show that silica sprays markedly suppress BN. In a study we conducted in 1994, meta-silicic acid $\left(\mathrm{SiO}_{2} \cdot n \mathrm{H}_{2} \mathrm{O}\right)$ suppressed $\mathrm{BN}$ as effectively as $\mathrm{Na}_{2} \mathrm{SiO}_{3}$, indicating that silica is the active agent and not $\mathrm{Na}$ (data not shown). Our results also support previous reports on the effectiveness of $\mathrm{Ca}$ sprays in suppressing BN (Meinken and Fischer, 1991; Wissemeyer et al., 1992; Woltz and Harbaugh, 1986).

Stromme et al. (1994) associated BN with a Ca concentration $<0.16 \%$ dry mass and a $\mathrm{K}$ : Ca ratio >20 in bract margin tissue of 'Lilo'. In our Expt. 1, the nontreated and the medium drenched 'Supjibi Red' plants had Ca concentrations $>0.19 \%$ dry mass in bract margin tissue and $\mathrm{K}:$ Ca ratios <20. Nevertheless, the bracts had a high incidence and acute severity of BN. Sprays of sodium silicate protected against $\mathrm{BN}$, even though $\mathrm{Ca}$ and $\mathrm{K}$ levels in bract margins were similar in plants from all treatments. Thus, the protective effect of silica was not related to alteration of $\mathrm{Ca}$ or K concentrations in bract margin tissue.

While it is clear that silica sprays at rates as low as $3.56 \mathrm{~mm}$ are as effective as $9.98 \mathrm{~mm} \mathrm{Ca}$ sprays at reducing the incidence and severity of $\mathrm{BN}$ in poinsettia for up to 30 days after initial anthesis, it is not clear how either treatment works. Although not considered an essential nutrient for most terrestrial plants (Epstein, 1994), silica altered the microdistribution of Mn in barley (Lewin and Reimann, 1969) and bean (Phaseolus vulgaris L.) leaves (Horst and Marschner, 1978), and ameliorated Al toxicity (Baylis et al., 1994). In cucumber (Cucumis sativus L.), silica also moderated the effects of a $\mathrm{P}: \mathrm{Zn}$ imbalance (Marschner et al., 1990). However, in our study, there was no indication of toxic concentrations of $\mathrm{Mn}$ or $\mathrm{Al}$ in tissues of bract margins of nontreated plants. Neither was there an imbalance of $\mathrm{P}$ and $\mathrm{Zn}$ in bract margin tissues that could be associated with the BN. Unless 


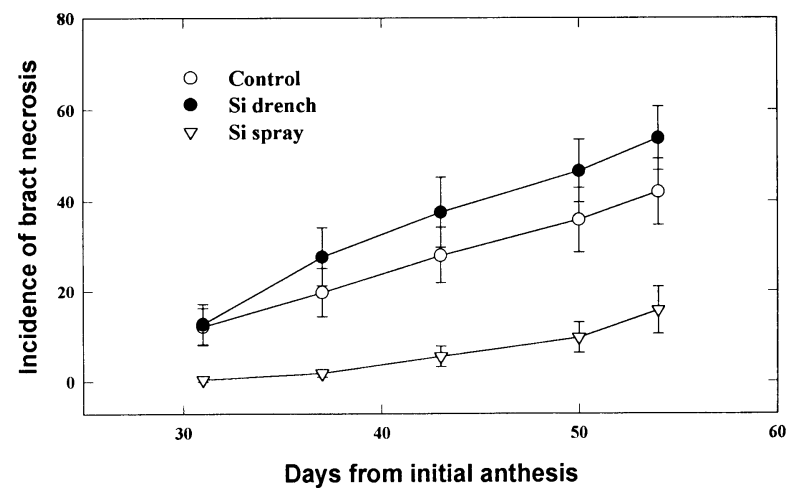

Fig. 1. Effect of $\mathrm{Na}_{2} \mathrm{SiO}_{3}(17.8 \mathrm{~mm})$ spray and medium drench treatments, relative to nonsprayed controls, on the incidence of bract necrosis in 'Supjibi' poinsettia over time. Treatments were applied at weekly intervals, beginning with initial bract coloration and ending at initial anthesis. The incidence of bract necrosis is expressed as the percentage of bracts with necrotic lesions relative to the total number of bracts on the plant. Vertical bars represent SE of the means; SE bars smaller than symbols do not appear on graph (Expt. 1).

Table 1. Percent incidence of bract necrosis (BN) and total necrosis index (TNI) at final harvest, 47 days after intial anthesis, on the poinsettias 'Angelika White' and 'Supjibi Red'. Plants were sprayed with either sodium silicate (four rates), calcium chloride, deionized water, or left untreated (Expt. 2).

\begin{tabular}{|c|c|c|c|c|c|c|}
\hline \multirow{4}{*}{$\begin{array}{l}\text { Compound } \\
\text { and concn (mM) }\end{array}$} & \multicolumn{6}{|c|}{ Disorder } \\
\hline & \multicolumn{3}{|c|}{$\mathrm{BN}$ incidence $(\%)^{\mathrm{z}}$} & \multicolumn{3}{|c|}{$\mathrm{TNI}^{\mathrm{y}}$} \\
\hline & \multicolumn{6}{|c|}{ Cultivar } \\
\hline & Angelika White & \multicolumn{2}{|r|}{ Supjibi Red } & \multicolumn{2}{|c|}{ Angelika White } & Supjibi Red \\
\hline None $(\mathrm{CT})$ & 33.7 & & 36.2 & & 184 & 208 \\
\hline $\mathrm{DI} \mathrm{H}_{2} \mathrm{O}$ (DI) & 25.6 & & 28.3 & & 163 & 172 \\
\hline $\mathrm{CaCl}_{2}(9.98)$ & 1.2 & & 0.6 & & 101 & 101 \\
\hline $\mathrm{Na}_{2} \mathrm{SiO}_{3}(1.78)$ & 12.5 & & 15.0 & & 125 & 133 \\
\hline (3.56) & 9.9 & & 11.6 & & 116 & 124 \\
\hline (5.34) & 6.7 & & 12.0 & & 112 & 126 \\
\hline \multirow[t]{3}{*}{ (7.12) } & 6.6 & & 9.3 & & 112 & 118 \\
\hline & \multicolumn{5}{|c|}{ Summary of significant effects } & \\
\hline & df & F value & $\underline{\text { Signi }}$ & & F value & Significance \\
\hline Cultivar & 1 & 4.59 & $P \leq$ & & 7.93 & $P \leq 0.01$ \\
\hline Treatment & 6 & 64.11 & $P \leq$ & & 55.04 & $P \leq 0.001$ \\
\hline MSE & & & & & & 413.13 \\
\hline \multirow[t]{2}{*}{$\mathrm{LSD}_{\text {trts }}$} & & & & & & 13 \\
\hline & \multicolumn{6}{|c|}{ Single-degree-of-freedom orthogonal contrasts } \\
\hline CT vs. all sprays & & & $P \leq$ & & & $P \leq 0.001$ \\
\hline DI vs. $\mathrm{Ca}$ and $\mathrm{Si}$ sprays & & & $P \leq$ & & & $P \leq 0.001$ \\
\hline Ca vs. Si (all rates) & & & $P \leq$ & & & $P \leq 0.001$ \\
\hline Ca vs. Si $7.12 \mathrm{~mm}$ & & & $P \leq$ & & & $P \leq 0.05$ \\
\hline $\mathrm{Si}$ (linear) & & & $P \leq$ & & & $P \leq 0.05$ \\
\hline
\end{tabular}

${ }^{\mathrm{x}}$ Each value is the mean of 10 observations.

${ }^{y}$ The TNI was calculated by multiplying the severity rating by the number of bracts in each category and then dividing the sum of this value $(\times 100)$ by the total number of bracts. This value represents the percent of the total bracts with necrosis, weighted for severity on a scale of 100 (least damage) to 600 (most damage).

small areas of nutrient concentration, not measurable by our sampling technique, give rise to necrotic spots, BN was not associated with the concentrations of any macro- or micronutrient in tissues of bract margins.

Nell and Barrett (1986) postulated salt transport through the pitted vein ending could lead to BN. Blom (1994) suggested that increased $\mathrm{BN}$ may be associated with guttation. This evidence is consistent with the slight protection observed against $\mathrm{BN}$ afforded by the deionized water spray (Table 1). Deionized water spray could have a diluting effect or the surfactant could disperse toxic droplets, thereby reducing the risk of localized damage (Neumann and Prinz, 1975). While linking of BN with guttation is intriguing, we have never observed guttation on poinsettia bracts and
Metcalfe and Chalk (1979) do not list any of the genera in the family Euphorbiaceae as having hydathodes. Furthermore, Van Berkel (1988) observed the least tipburn in Chinese cabbage plants that guttate the most.

The symptoms of $\mathrm{BN}$ are distinct from those caused by localized $\mathrm{Ca}$ deficiencies in green leafy tissues in that the first visible evidence of necrosis occurs after cell expansion is completed. In our studies, initial symptoms of $\mathrm{BN}$ appeared after poinsettias reached anthesis (Figs. 1 and 3). Others (Nell and Barrett, 1986; Woltz and Harbaugh, 1986) observed initial $\mathrm{BN}$ at a similar stage of bract development. These observations do not rule out the disorder occurring earlier in bract development, but not manifesting itself until bracts mature. On both 'Supjibi Red' and
'Angelika White' bracts, BN appeared at the looped ends of lateral veins that displayed the closed-vein pattern (Fig. 2). However, Nell and Barrett (1986) observed that necrotic lesions first appeared on 'V-14 Glory' bracts at lateral veins that ended in a blind-end pattern; damage rarely occurred on the veins that had a closed-end or loop pattern.

With localized $\mathrm{Ca}$ deficiencies in crops such as celery and Chinese cabbage, visible necrosis occurs in rapidly expanding leaf tissue (Shear, 1975). With these developmental disorders, impaired membrane function-resulting in membrane leakiness-causes the tissue damage (Bangerth, 1979). If $\mathrm{BN}$ is primarily a Ca deficiency disorder caused by impaired membrane function during bract development, then, to suppress this disorder, silica would have to substitute for $\mathrm{Ca}$. We know of no reports of silicates substituting for the metabolic or structural functions of intracellular $\mathrm{Ca}$ in higher plants. This fact is not surprising in that silica and $\mathrm{Ca}$ are dissimilar chemical species.

With topical application of $\mathrm{Ca}$, there is a question as to whether it actually enters the cytosol. The concentration of intracellular $\mathrm{Ca}$ is low (submicromolar) and carefully regulated by the cell. In contrast, extracellular $\mathrm{Ca}$ concentrations are in the millimolar range (Helper and Wayne, 1985). Extracellular Ca concentrates in the cell wall and middle lamella, strengthening the walls; however, cell wall integrity is less of a problem with developmental $\mathrm{Ca}$ disorders and more important for disease resistance. Silica can contribute to cell wall strength and it has been used to suppress powdery mildews in cucumber (Menzies et al., 1992) and grapes (Vitis vinifera L.) (Bowen et al., 1992). Or, by strengthening cell walls, silica and Ca may be preventing laticifer rupture (Tibbitts et al., 1985) and consequent damage analogous to tipburn of lettuce.

Whatever the etiology of $\mathrm{BN}$, if it is a $\mathrm{Ca}$ deficiency disorder, then we have reported the first instance of silica partially rectifying a deficiency symptom of Ca. Finally, while silica is not a cure for this disorder, investigating its mode of action may give further clues into the nature of $\mathrm{BN}$.

\section{Literature Cited}

Bangerth, F. 1979. Calcium-related physiological disorders of plants. Annu. Rev. Phytopathol. 17:97122.

Baylis, A.D., C. Gragopoulou, K.J. Davidson, and J.D. Birchall. 1994. Effects of silicon on the toxicity of aluminium to soybean. Communications in Soil Sci. \& Plant Analysis 25:537-546.

Bible, B.B. and B. Stiehl. 1986. Effect of atmospheric modification on the incidence of blackheart and cation content of celery. Scientia Hort. 28:19-28.

Bierman, P.M., C.J. Rosen, and H.F. Wilkins. 1990. Leaf edge burn and axillary shoot growth of vegetative poinsettia plants: Influence of calcium, nitrogen form, and molybdenum. J. Amer. Soc. Hort. Sci. 115:73-78.

Blatt, C.R. and A. van Diest. 1981. Evaluation of a screening technique for manganese toxicity in relation to leaf manganese distribution and interaction with silicon. Neth. J. Agr. Sci. 29: 297-304.

Blom, T.J. 1994. Bract edge burn on poinsettias. Cana- 


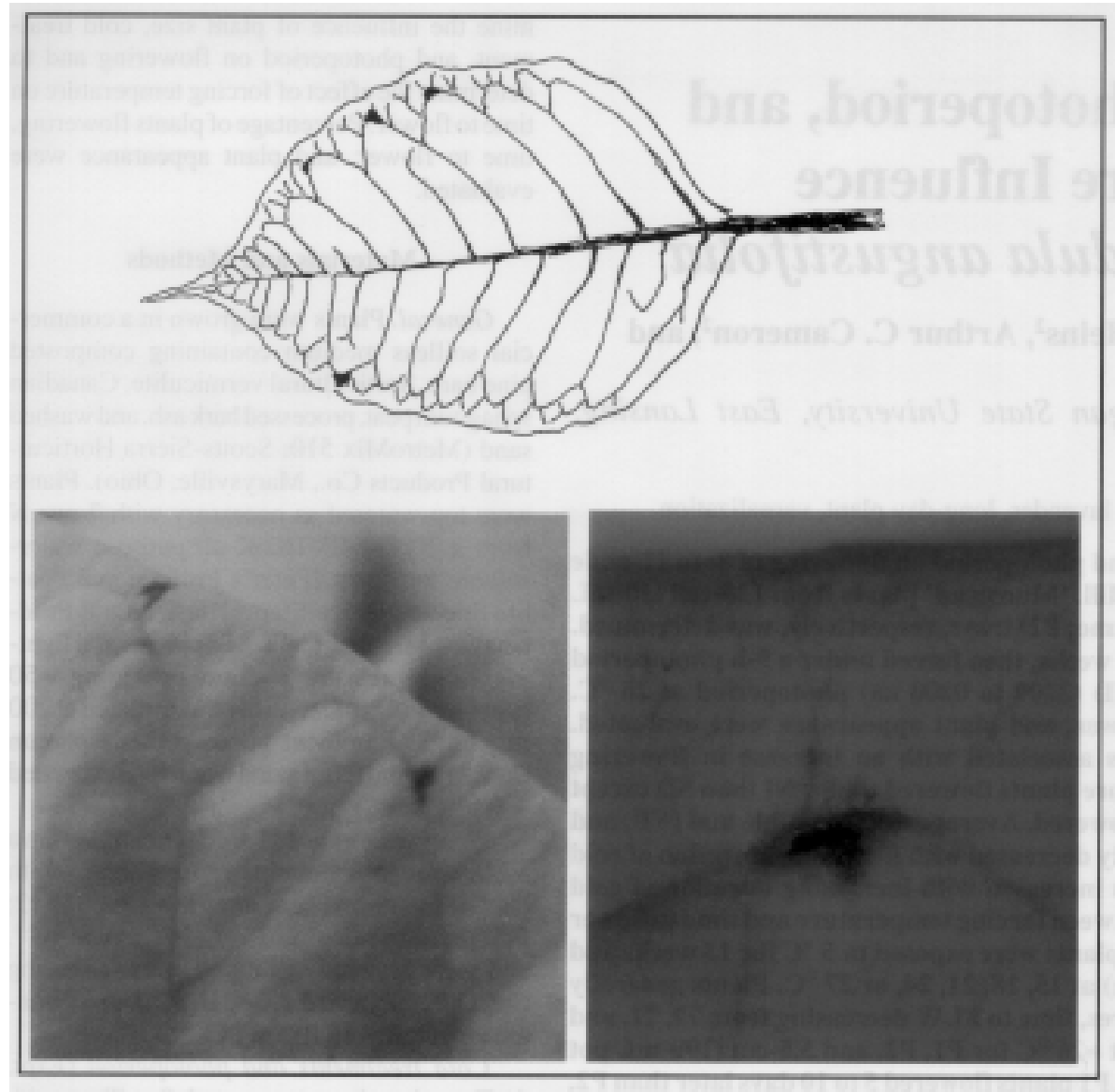

Fig. 2. Necrotic lesions on poinsettia bracts typical of bract necrosis. (top) Schematic representation of a poinsettia bract showing necrotic lesions developing at the looped-end of lateral veins near the bract margins, (bottom left) photograph of 'Angelika White' bract with necrotic lesions near lateral veins on bract margin, (bottom right) photograph of 'Supjibi' with necrotic lesion beginning to develop on looped-end of lateral vein.

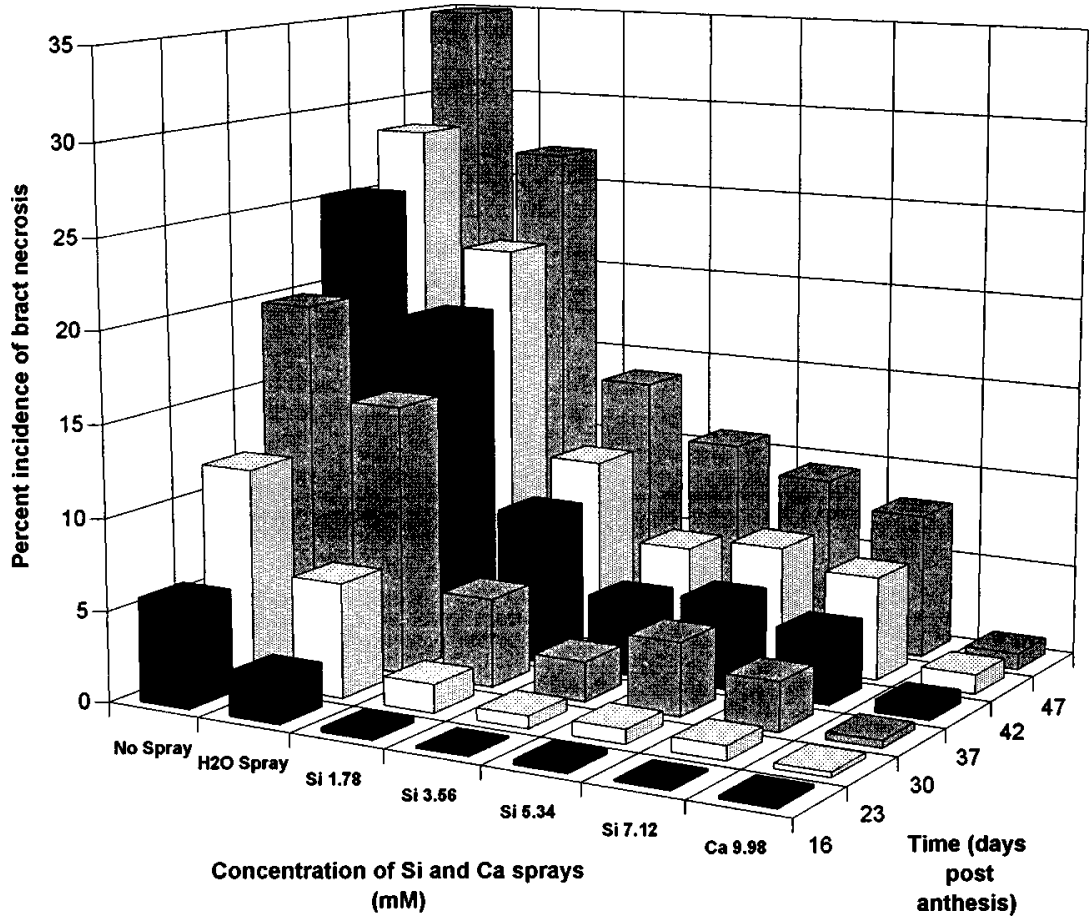

Fig. 3. Development of bract necrosis (percentage of total bracts with necrotic spots) over time for nontreated poinsettias, or poinsettias sprayed with $\mathrm{CaCl}_{2}(9.98 \mathrm{~mm})$, or $\mathrm{Na}_{2} \mathrm{SiO}_{3}(1.78,3.56,5.34$, or $7.12 \mathrm{~mm})$, or deionized water. Data represent mean values for the cultivars 'Supjibi Red' and 'Angelika White'; both cultivars showed a similar response to treatments. LSD values for each sample date were 1.4 (day 16), 2.2 (day 23), 3.3 (day 30), 3.4 (day 37), 3.7 (day 42), and 4.1 (day 47). dian Florist Greenhouse \& Nursery 89:38-39.

Bowen, P., J. Menzies, D. Ehret, L. Samuels, and A.D.M. Glass. 1992. Soluble silicon sprays inhibit powdery mildew development in grape leaves. J. Amer. Soc. Hort. Sci. 117:906-912.

Elawad, S.H., J.J. Street, and G.J. Gascho. 1982. Response of sugarcane to silicate source and rate. II. Leaf freckling and nutrient content. Agron. J. 74:484-487.

Epstein, E. 1994. The anomaly of silicon in plant biology. Proc. Natl. Acad. Sci. USA 91:11-17.

Helper, K.H. and R.O. Wayne. 1985. Calcium and plant development. Annu. Rev. Plant Physiol. 36:397439.

Horst, W.J. and H. Marschner. 1978. Effect of silicon on manganese tolerance of bean plants (Phaseolus vulgaris L.). Plant and Soil 50:287-303.

Jacques, D.J, R.E.J. Boerner, and J.C. Peterson. 1990 Effects of Ca supply and stress on uptake and translocation of $\mathrm{Ca}$ in two poinsettia cultivars. Environmental and Experimental Botany 30(4): $525-531$.

Lewin, J., and B.E.F. Reimann. 1969. Silicon and plant growth. Annu. Rev. Plant Physiol. 20:289-304.

Marschner, H., H. Oberle, I. Cakmak, and V. Romheld. 1990. Growth enhancement by silicon in cucumber (Cucumis sativus) plants depends on imbalance in phosphorus and zinc supply. Plant \& Soil 124:211219.

McAvoy, R.J. and B.B. Bible. 1994. Effect of antioxidants on bract necrosis in poinsettia. pp. 234-238. In: Richard J. McAvoy (ed.). Proc. 1994 New England Greenhouse Conf., Sturbridge, Mass.

Meinken, E. und P. Fischer. 1991. BrakteenRandnekrosen bei Poinsettien-Spate Calciumchlorid-Spritzungen schaffen. Deutscher Gartenbau 45:3064-3066.

Menzies, J., P. Bowen, D. Ehret, and A.D.M. Glass. 1992. Foliar applications of potassium silicate reduce severity of powdery mildew on cucumber, muskmelon, and zucchini squash. J. Amer. Soc. Hort. Sci. 117:902-905.

Metcalfe, C.R. and L. Chalk. 1979. Anatomy of the dicotyledons. Vol 2. Claredon Press, Oxford.

Moe, R., T. Fjeld, and L.M. Mortensen. 1992. Stem elongation and keeping quality in poinsettia ( $E u-$ phorbia pulcherrima Willd.) as affected by temperature and supplementary lighting. Scientia Hort. 50:127-136.

Nell, T.A. and J.E. Barrett. 1986. Growth and incidence of bract necrosis in 'Gutbier V-14 Glory' poinsettia. J. Amer. Soc. Hort. Sci. 111:266-269.

Neumann, P.M. and R. Prinz. 1975. The reduction by surfactants of leaf burn resulting from foliar sprays and a salt-induced inhibition of the effect. J. Sci. Fd. Agric. 26:909-914.

Shear, C.B. 1975. Calcium-related disorders of fruits and vegetables. HortScience 10:361-365.

Stromme, E., R.Selmer-Olsen, H.R. Gislerod, and R. Moe. 1994. Cultivar differences in nutrient absorption and susceptibility to bract necrosis in poinsettia (Euphorbia pulcherrima Willd. ex Klotzch). Gartenbauwissenschaft 59(1) S. 6-12.

Tibbitts, T.W., J. Bensink, F. Kuiper, and J. Hobe. 1985. Association of latex pressure with tipburn injury of lettuce. J. Amer. Soc. Hort. Sci. 110:362-365.

Van Berkel, N. 1988. Preventing tipburn in chinese cabbage by high relative humidity during the night. Neth. J. Agric. Sci. 36:301-308.

Williams, D.E. and J. Vlamis. 1957. Manganese toxicity in standard culture solution. Plant \& Soil 8:183193.

Wissemeyer, A.H., F. Weinhold, and D.J. Horst. 1992. Brakteen-Schaden bei Poinsettien - Abhilfe durch Calcium-Spritzungen. Gartnerborse+Gartenwelt 92:2472.

Woltz, S.S. and B.K. Harbaugh. 1986. Calcium deficiency as the basic cause of marginal bract necrosis of 'Gutbier V-14 Glory' poinsettia. HortScience 21:1403-1404 